\title{
Steel treatment with calcium-aluminate synthetic slag and addition of titanium oxide ${ }^{(\bullet)}$
}

\author{
A. Putan*, V. Putan*, T. Heput* and A. Socalici*
}

\begin{abstract}
The paper introduces the results of the experiments on synthetic slag desulphurization and deoxidizing using slag belonging to the ternary system $\mathrm{CaO}-\mathrm{Al}_{2} \mathrm{O}_{3}-\mathrm{TiO}_{2}$. The experiments have been done in a $10 \mathrm{~kg}$ induction furnace. In order to obtain the reducing slag we used a mixture of lime, alumina and titanium oxide, representing $2 \%$ of the charge weight. The experiments were done on mechanical mixtures produced according to various recipes; for each experiment, the slag was sampled in order to determine its chemical composition and the steel was also sampled, in order to determine its contents in sulphur and oxygen. The resulting data have been processed in EXCEL, which gave the correlation equations between the desulphurization and deoxidizing output and the chemical composition of the synthetic slag, respectively the ratio and sum of the oxides.
\end{abstract}

\section{Tratamiento del acero con escorias sintéticas de calcio y aluminio con óxido de titanio añadido}

\begin{abstract}
Resumen
En el trabajo se presentan los resultados del experimento que se refiere a la desulfuración y desoxidación de las escorias sintéticas con escorias del sistema ternario $\mathrm{CaO}-\mathrm{Al}_{2} \mathrm{O}_{3}-\mathrm{TiO}_{2 . .}$ Los experimentos se hicieron en un horno con inducción de $10 \mathrm{~kg}$ de capacidad. Para formar las escorias reductoras se ha utilizado una mezcla compuesta de cal, alúmina y óxido de titanio en porcentaje de $2 \%$ del peso de la carga de acero más escoria sintética. Para los experimentos se usaron mezclas mecánicas producidas por varias recetas y de cada experimento se tomaron muestras de escorias para determinar la composición química y muestras de acero para determinar el contenido de azúfre y oxígeno. Los datos obtenidos fueron procesados en el programa de cálculo EXCEL, obteniéndose ecuaciones de correlación entre la eficiencia de la desulfuración y desoxidación y la composición química de la escoria sintética.
\end{abstract}

Palabras clave

\section{INTRODUCTION}

Steel refining with liquid slag or with various powdery mixtures of synthetic slag is based on the boosting of the passage of unwanted impurities (sulphur, nonmetallic suspensions, oxygen) from the molten steel into the slag, mainly by diffusion, or partially by draining some suspensions alongside with the synthetic slag particles which are decanted in the steel bath under treatment. Synthetic slag can also be obtained by addition of mechanical mixture, directly into the casting pot, in which case, in order to compensate the cooling of the steel inside the pot because of the additives (melting and overheating), the temperature of the steel has to be by more than 20-40 ${ }^{\circ} \mathrm{C}$ above the normal ${ }^{[1]}$. In practice, synthetic slag deoxidizing uses slag belonging to the following binary systems: $\mathrm{CaO}-\mathrm{Al}_{2} \mathrm{O}_{3} ; \mathrm{CaO}-\mathrm{TiO}_{2}$ and $\mathrm{CaO}-\mathrm{CaF}_{2}$ (with $57-70 \% \mathrm{CaF}_{2}$ ) or to the ternary systems: $\mathrm{CaO}-\mathrm{SiO}_{2}-\mathrm{Al}_{2} \mathrm{O}_{3}$ (a representative system for the blast furnace slag) and $\mathrm{CaO}-\mathrm{CaF}_{2}-\mathrm{Al}_{2} \mathrm{O}_{3}, \mathrm{CaO}-\mathrm{TiO}_{2}-\mathrm{Al}_{2} \mathrm{O}_{3}$. According to reference literature data, the best results were obtained with synthetic slag belonging to the binary system $\mathrm{CaO}-\mathrm{Al}_{2} \mathrm{O}_{3}$, with a $50-52 \%$ content of $\mathrm{CaO}$ and $38-42 \% \mathrm{Al}_{2} \mathrm{O}_{3}{ }^{[1]}$.

The influence of the slag components upon viscosity depends on the nature of the slag. Thus, researches have shown that the viscosity of blast

(•) Trabajo recibido el día 7 de febrero de 2012 y aceptado en su forma final el día 22 de junio de 2012.

* University Politehnica, Timisoara, Faculty of Engineering, Hunedoara. Str. Revoluției, N. ${ }^{\circ} 5,331128$ - Hunedoara, Romania.

E-mail: adriana.putan@fih.upt.ro 
furnace slag is directly proportional to the amount of $\mathrm{SiO}_{2}$ and $\mathrm{Al}_{2} \mathrm{O}_{3}$ and inversely proportional to the content of $\mathrm{CaO}, \mathrm{MgO}, \mathrm{FeO}, \mathrm{MnO}, \mathrm{Na}_{2} \mathrm{O}, \mathrm{CaS}, \mathrm{FeS}$ and $\mathrm{TiO}_{2}{ }^{[2]}$.

The viscosity of the synthetic slag is particularly influential when it comes to the physical and chemical processes occurring during the treatment of the molten steel, it having a high weight in the capacity of slag emulsification. An increase of slag viscosity from 0.15 to $0.45 \mathrm{Ns} / \mathrm{m}^{2}$ (1.5 to 4.5 Poise) leads to a $30 \%$ reduction of the steel-slag interaction surface. Such an increase of calcium-aluminate slag viscosity can be noticed when its temperature goes down, for instance from $1600{ }^{\circ} \mathrm{C}$ to $1470{ }^{\circ} \mathrm{C}$. It is then of utmost importance to grant, during steel processing with synthetic slag, an optimal temperature regime, specific to each type of slag in use, in order to obtain an appropriate fluidity (viscosity).

For the synthetic slag steel processing temperatures, the minimum viscosity is that of the slag containing $56 \% \mathrm{CaO}$; but, considering the industrial conditions, it is likely to have frequent deviations from this optimal composition (by 1-2\%) and reach unwanted values of over $57 \% \mathrm{CaO}$; therefore, in industrial practice, it is recommended to have a content of $52-54 \% \mathrm{CaO}$ in the slag, amount for which normal composition deviation cannot trigger abrupt increases of viscosity.

The viscosity of synthetic slag is also influenced by the other components; thus, it can significantly increase for a higher content of $\mathrm{SiO}_{2}$, while contents of $\mathrm{MgO}$ of up to $8 \%$ are favorable. For temperatures exceeding $1500{ }^{\circ} \mathrm{C}$, the introduction of $\mathrm{TiO}_{2}$ into the calciumaluminate slag leads to a slight decrease of viscosity.

Usually, the chemical structure of the synthetic slag belonging to the system $\mathrm{CaO}-\mathrm{Al}_{2} \mathrm{O}_{3}$ most often used in practice, ranges within the following limits: $\mathrm{CaO}=48-55 \% ; \mathrm{Al}_{2} \mathrm{O}_{3}=40-45 \% ; \mathrm{SiO}_{2}$ maximum $3,0 \% ; \mathrm{MgO} \max .3 \%$ and $\mathrm{FeO} \max .1 \%$, the rest being other oxides ${ }^{[3}$ and 4$]$.

As the rate of diffusion into the slag increases with temperature $T$ and with the reduction of viscosity $\eta$, it results that synthetic slag viscosity, respectively its fluidity $\phi=1 / \eta$ is particularly important in the process of steel treatment with synthetic slag.

Also, the larger the contact surface between the synthetic slag and the metal bath, the faster the passage into the slag of the elements under consideration, this aspect being, alongside with viscosity, fundamental in steel treatment with synthetic slag ${ }^{[5]}$.

\section{EXPERIMENTAL}

Starting from the above-mentioned considerations, a series of laboratory experiments have been done in order to determine the influence of the slag chemical composition and of the ratios between various oxides upon the degree of desulphurization and oxidizing.

The laboratory experiments have been done in an induction furnace with the following characteristics: capacity $10 \mathrm{~kg}$; crucible diameter $97 \mathrm{~mm}$; crucible height $220 \mathrm{~mm}$; frequency $100 \mathrm{kHz}$; transformer power $150 \mathrm{KVA}$; primary voltage $500 \mathrm{~V}$; secondary voltage $167 \mathrm{~V}$; variable voltage 100/83/50 V; power on high frequency $50 \mathrm{~kW}$.

The charge of the furnace consisted in carbon steel scrap, more exactly leftovers of samples used in the determination of chemical composition of steel elaborated in electric steel plants and leftovers from refining pig iron samples.

In order to determine the melting conditions, steel temperature was measured and a sample was collected in order to determine the chemical composition (the content in sulphur being of particular interest) and the content in oxygen, melting duration ranging within 30-40 min.

In order to determine the influence of the chemical composition of the synthetic slag (resulting from the melting of the reducing mixture), mechanical mixtures were produced according to several recipes (16 recipes in all), for each of them the chemical composition being varied, while keeping the treatment time constant, i.e. $8 \mathrm{~min}$. The mechanical mixture was made of lime, alumina and titanium oxide, so that the structure of the resulting reducing slag corresponds to the ternary system $\mathrm{CaO}-\mathrm{Al}_{2} \mathrm{O}_{3}-\mathrm{TiO}_{2}\left(\mathrm{CaO}=48-55 \%, \mathrm{Al}_{2} \mathrm{O}_{3}=34-41 \%\right.$, $\mathrm{TiO}_{2}=3-6.25 \%$ ) (Table I).

During the experiments, before the deoxidizing treatment with synthetic slag, the molted slag was removed from the surface of the metal bath and then the bath was covered with a slag layer of the same quality as the experimental one (made according to the same recipe, in order to confirm as clearly as possible the influence of the chemical composition upon the refining process), more exactly $150 \mathrm{~g}$ of mixture were added to the metal bath.

After the slag was formed on the surface of the metal bath, $200 \mathrm{~g}$ of reducing mixture was immersed into the bath (representing $20 \%$ ). The mixture was introduced into a metallic cartridge (made of thin steel plate), attached to a wooden rod, and it was kept at the bottom of the crucible until complete melting; all along this process $(8 \mathrm{~min})$, the metal bath was stirred, it being also agitated by the induction phenomenon.

After 8 min of treatment with reducing slag (respectively before tapping and casting the steel into $4 \times 2 \mathrm{~kg}$ ingots), steel samples were collected from the 
STEEL TREATMENT WITH CALCIUM-ALUMINATE SYNTHETIC SLAG AND ADDITION OF TITANIUM OXIDE TRATAMIENTO DEL ACERO CON ESCORIAS SINTÉTICAS DE CALCIO Y ALUMINIO CON ÓXIDO DE TITANIO AÑADIDO

Table I. Results of experiments

Tabla I. Resultados de los experimentos

\begin{tabular}{|c|c|c|c|c|c|c|c|c|c|c|c|}
\hline \multirow{2}{*}{ N. ${ }^{\circ}$} & \multicolumn{5}{|c|}{ Chemical composition, \% } & \multicolumn{4}{|c|}{$\begin{array}{l}\text { The values of various ratios } \\
\text { between oxides and slags }\end{array}$} & \multicolumn{2}{|c|}{ Output } \\
\hline & 1) $\mathrm{CaO}$ & 2) $\mathrm{Al}_{2} \mathrm{O}_{3}$ & 3) $\mathrm{TiO}_{2}$ & $A+T$ & $C+A+T$ & C/A & $\mathrm{C} / \mathrm{T}$ & $C / A+T$ & $A / T$ & $\eta_{s}$ & $\eta_{0}$ \\
\hline 1 & 48.02 & 41.03 & 3.00 & 44.03 & 92.05 & 1.171 & 16.00 & 1.09 & 13.66 & 20.51 & 30.51 \\
\hline 2 & 48.52 & 40.51 & 3.25 & 43.76 & 92.28 & 1.198 & 14.92 & 1.10 & 12.46 & 25.02 & 26.90 \\
\hline 3 & 49.11 & 40.08 & 3.52 & 43.60 & 92.71 & 1.225 & 14.00 & 1.12 & 11.42 & 35.04 & 39.52 \\
\hline 4 & 49.51 & 39.51 & 3.75 & 43.26 & 92.77 & 1.253 & 13.20 & 1.14 & 10.53 & 38.05 & 38.06 \\
\hline 5 & 50.01 & 39.04 & 4.04 & 43.08 & 93.09 & 1.282 & 12.50 & 1.16 & 9.75 & 41.11 & 41.02 \\
\hline 6 & 50.54 & 38.51 & 4.25 & 42.76 & 92.30 & 1.312 & 11.88 & 1.18 & 9.05 & 44.02 & 44.04 \\
\hline 7 & 51.03 & 38.05 & 4.52 & 42.57 & 93.60 & 1.342 & 11.33 & 1.20 & 8.44 & 48.01 & 4812 \\
\hline 8 & 51.52 & 37.52 & 4.75 & 42.27 & 93.79 & 1.373 & 10.84 & 1.21 & 7.89 & 53.12 & 52.98 \\
\hline 9 & 52.05 & 37.03 & 5.05 & 42.08 & 94.13 & 1.405 & 10.40 & 1.23 & 7.40 & 55.05 & 54.96 \\
\hline 10 & 52.50 & 36.51 & 5.25 & 41.76 & 94.26 & 1.438 & 10.00 & 1.25 & 95 & 54.03 & 54.03 \\
\hline 11 & 53.07 & 36.02 & 5.51 & 41.53 & 94.60 & 1.472 & 9.63 & 1.27 & 6.54 & 53.10 & 52.99 \\
\hline 12 & 53.51 & 35.50 & 5.75 & 41.25 & 94.76 & 1.507 & 9.30 & 1.29 & 6.17 & 52.04 & 51.02 \\
\hline 13 & 54.04 & 35.05 & 6.03 & 41.08 & 95.12 & 1.543 & 9.00 & 1.31 & 5.83 & 50.11 & 50.12 \\
\hline 14 & 54.5 & 34.50 & 6.25 & 40.75 & 94.80 & 1.580 & 8.72 & 1.33 & 5.52 & 47.03 & 47.03 \\
\hline 15 & 55.1 & 34.03 & 6.05 & 40.08 & 95.08 & 1.618 & 9.16 & 1.37 & 5.66 & 42.02 & 42.09 \\
\hline 16 & 54.08 & 34.71 & 6.15 & 40.86 & 94.94 & 1.558 & 8.79 & 1.32 & 5.64 & 42.74 & 41.98 \\
\hline
\end{tabular}

1) $\mathrm{CaO}=\mathrm{C}$; ${ }^{2)} \mathrm{Al}_{2} \mathrm{O}_{3}=\mathrm{A}$; $\left.{ }^{3}\right) \mathrm{TiO}_{2}=\mathrm{T}$.

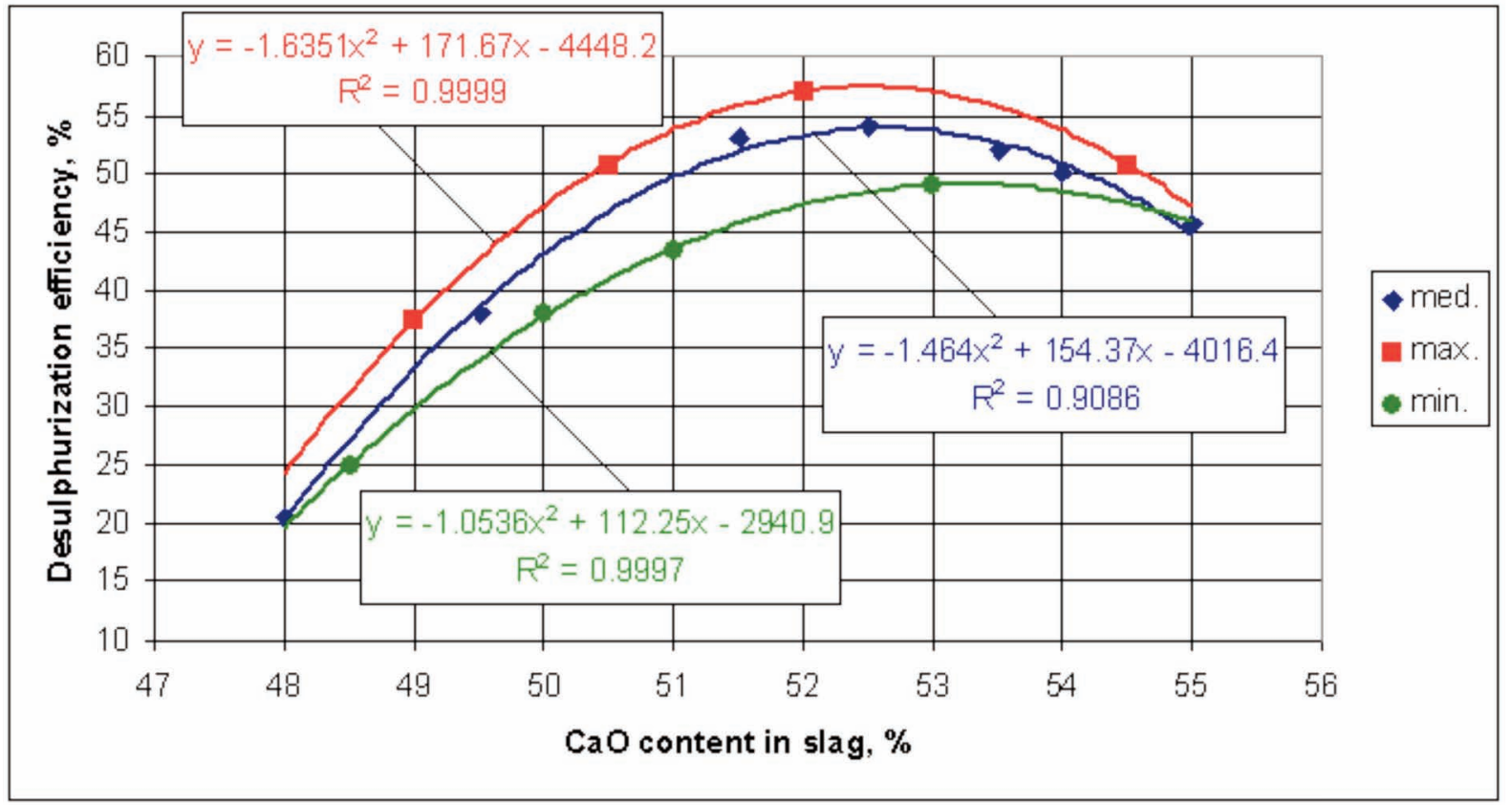

Figure 1. Desulphurization efficiency depending on the content of $\mathrm{CaO}$ in slag.

Figura 1. Eficiencia de la desulfuración en función del contenido de CaO en la escoria.

furnace in order to determine the content of sulphur and oxygen; slag was also sampled in order to determine its chemical composition $(\% \mathrm{CaO}$, $\% \mathrm{Al}_{2} \mathrm{O}_{3}$ and $\% \mathrm{TiO}_{2}$ ). 


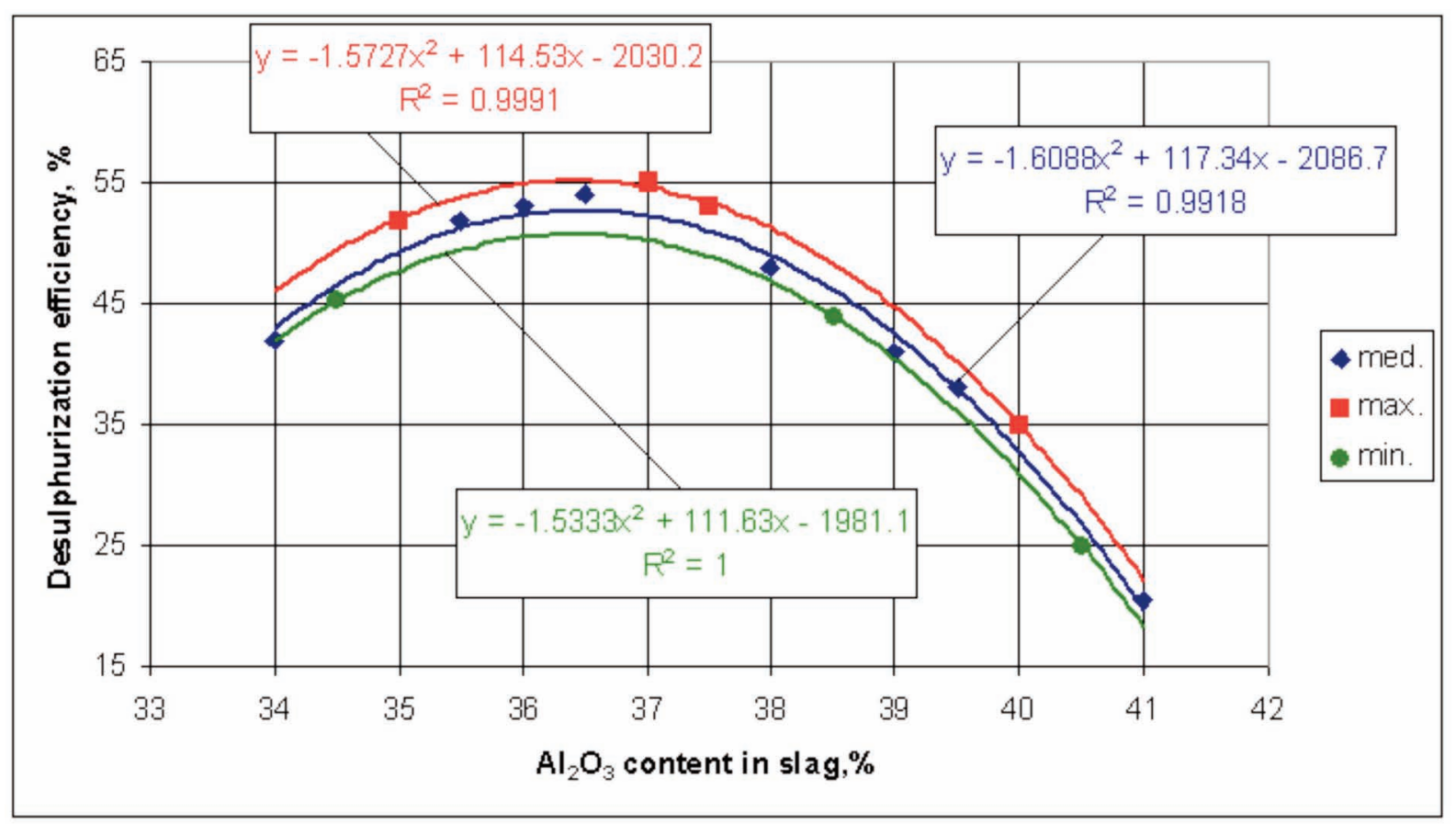

Figure 2. Desulphurization efficiency depending on the content of $\mathrm{Al}_{2} \mathrm{O}_{3}$ in slag.

Figura 2. Eficiencia de la desulfuración en función del contenido de $\mathrm{Al}_{2} \mathrm{O}_{3}$ en la escoria.

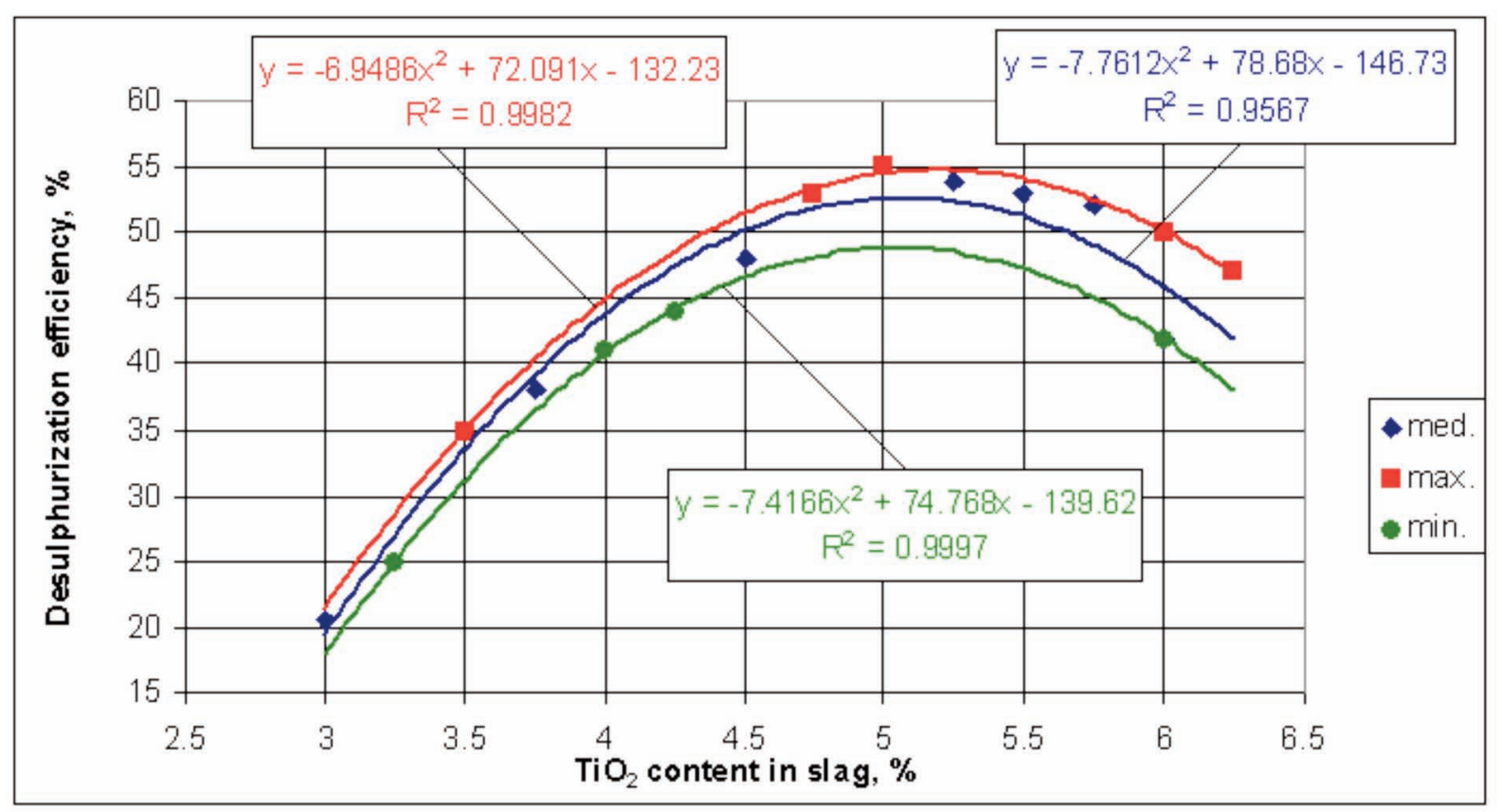

Figure 3. Desulphurization efficiency depending on the content of $\mathrm{TiO}_{2}$ in slag.

Figura 3. Eficiencia de la desulfuración en función del contenido de $\mathrm{TiO}_{2}$ en la escoria.

\section{RESULTS}

In order to establish the technological correlations between the parameters under consideration, the technological data resulting from the laboratory experiments were checked from the technological point of view and then processed in EXCEL.

At the first stage, the correlations established were of linear, $2^{\text {nd }}, 3^{\text {rd }}$ and $4^{\text {th }}$ degree polynomial, logarithmic and exponential type. It was 
STEEL TREATMENT WITH CALCIUM-ALUMINATE SYNTHETIC SLAG AND ADDITION OF TITANIUM OXIDE TRATAMIENTO DEL ACERO CON ESCORIAS SINTÉTICAS DE CALCIO Y ALUMINIO CON ÓXIDO DE TITANIO AÑADIDO

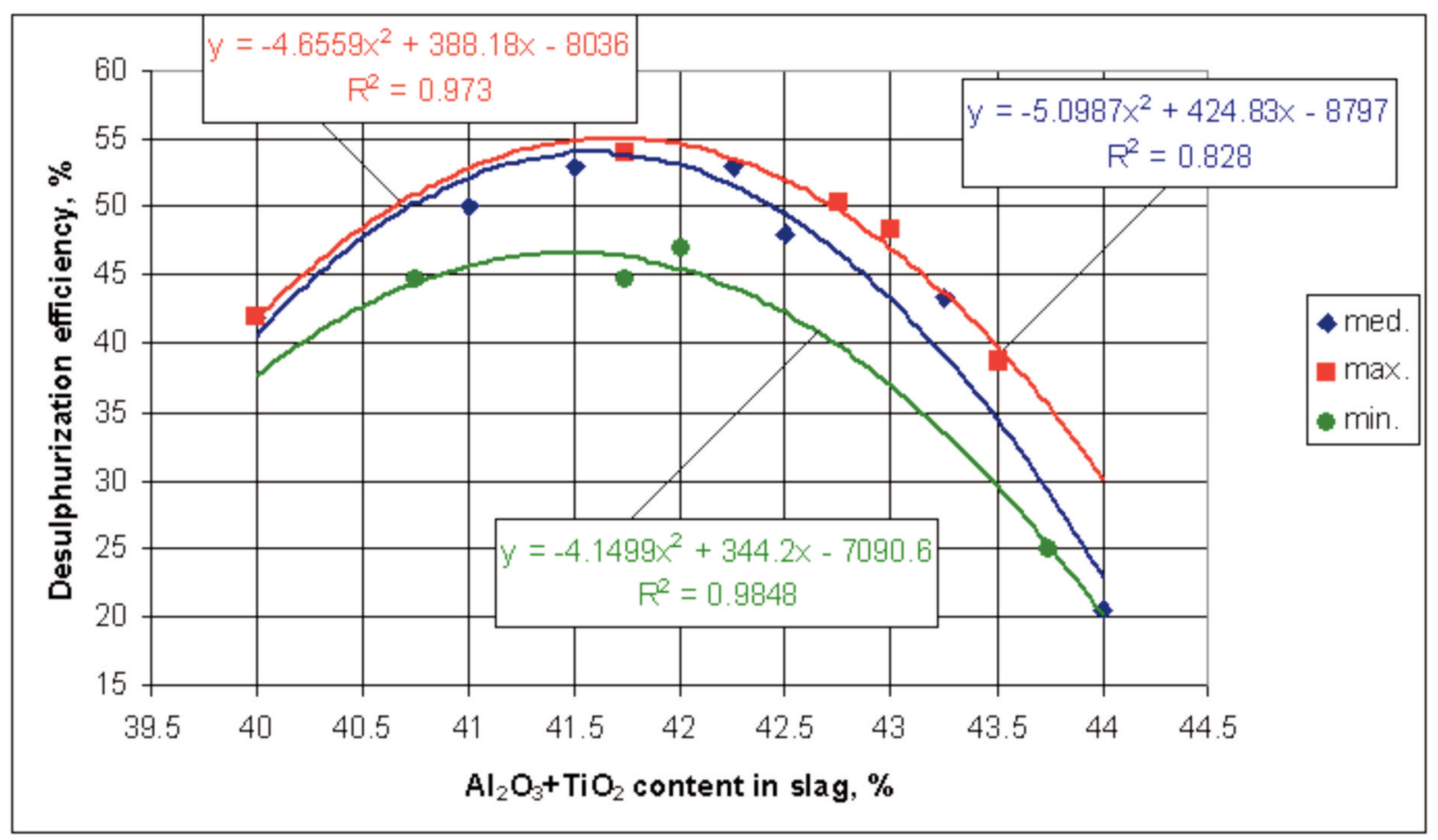

Figure 4. Desulphurization efficiency depending on the content of $\mathrm{Al}_{2} \mathrm{O}_{3}+\mathrm{TiO}_{2}$ in slag.

Figura 4. Eficiencia de la desulfuración en función del contenido de $\mathrm{Al}_{2} \mathrm{O}_{3}+\mathrm{TiO}_{2}$ en la escoria.

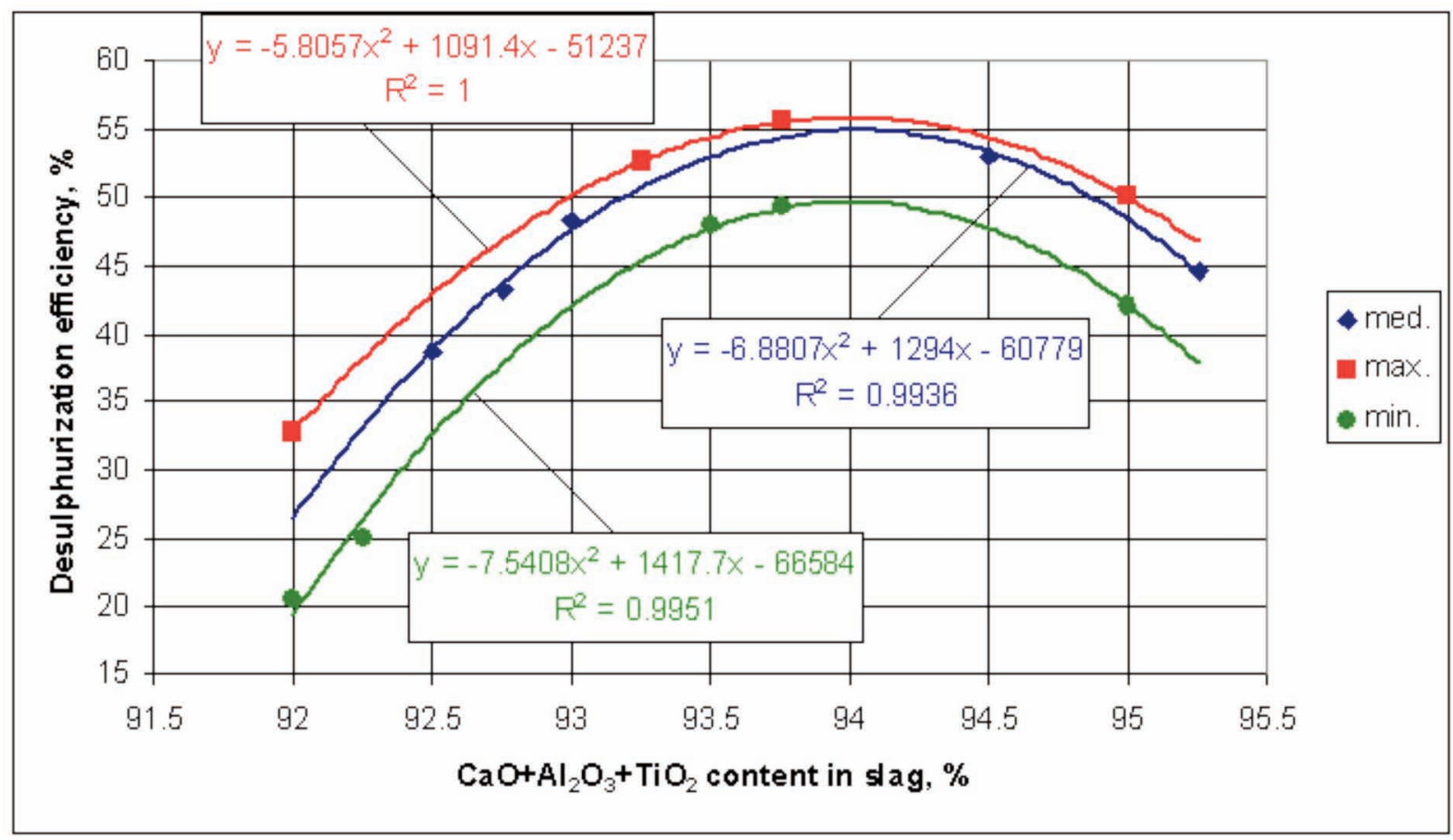

Figure 5. Desulphurization efficiency depending on the content of $\mathrm{CaO}+\mathrm{Al}_{2} \mathrm{O}_{3}+\mathrm{TiO}_{2}$ in slag.

Figura 5. Eficiencia de la desulfuración en función del contenido de $\mathrm{CaO}+\mathrm{Al}_{2} \mathrm{O}_{3}+\mathrm{TiO}_{2}$ en la escoria. 


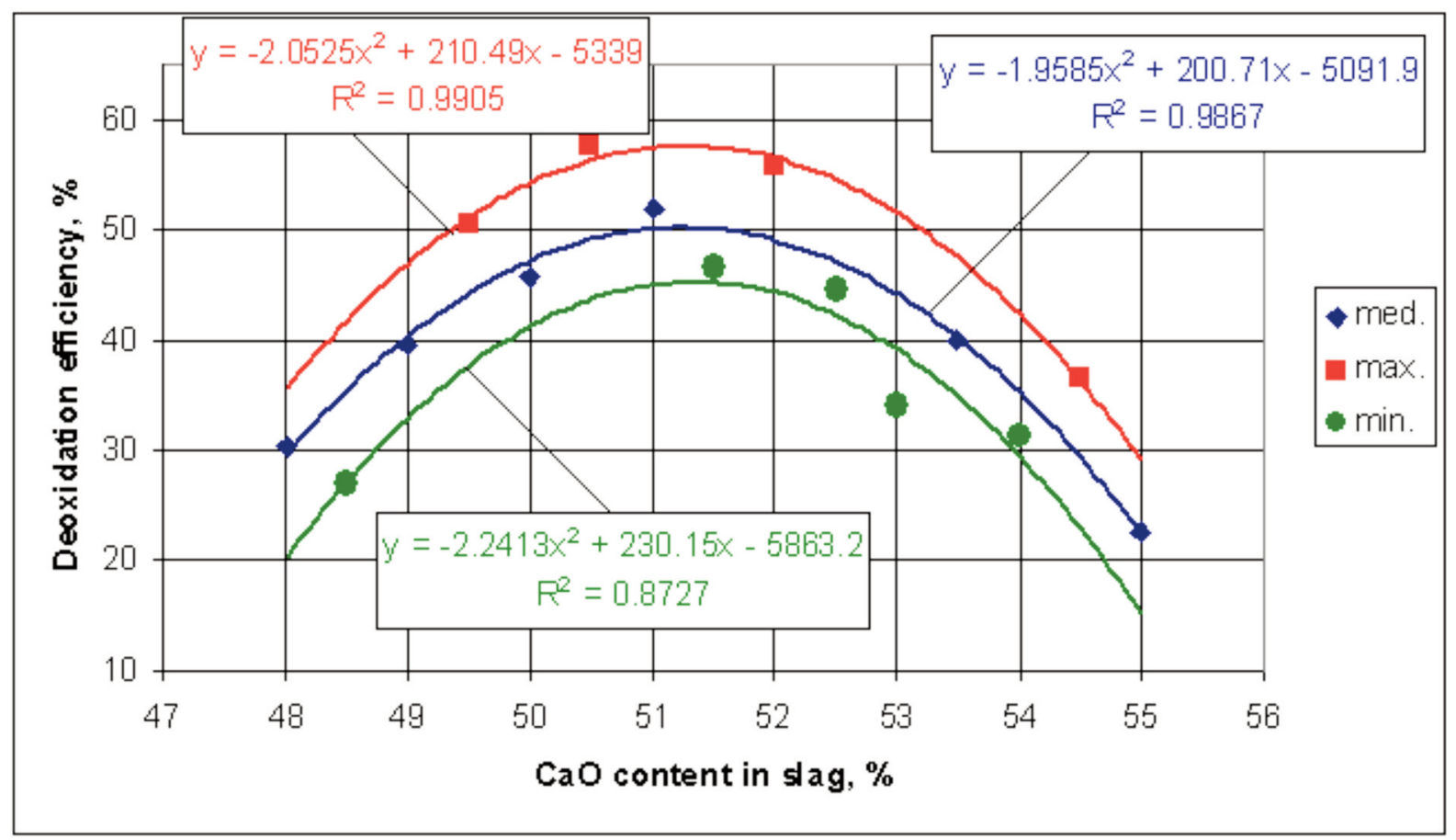

Figure 6. Deoxidation efficiency depending on the content of $\mathrm{CaO}$ in slag.

Figura 6. Eficiencia de la desoxidación en función del contenido de CaO en la escoria.

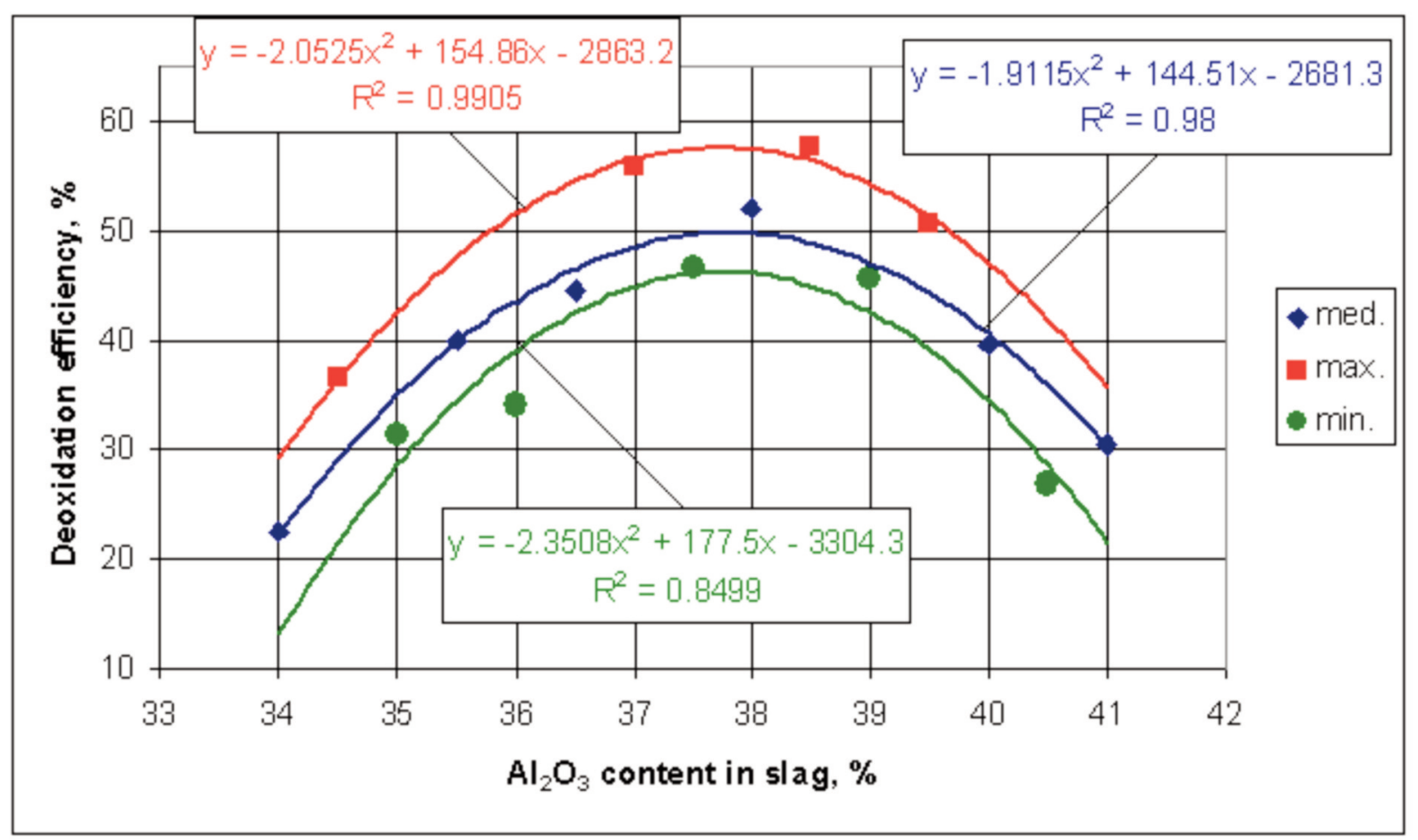

Figure 7. Deoxidation efficiency depending on the content of $\mathrm{Al}_{2} \mathrm{O}_{3}$ in slag.

Figura 7. Eficiencia de la desoxidación en función del contenido de $\mathrm{Al}_{2} \mathrm{O}_{3}$ en la escoria.

Each correlation obtained from the calculation program was presented both in analytical and in graphic form and they were analyzed from the technological point of view. 
STEEL TREATMENT WITH CALCIUM-ALUMINATE SYNTHETIC SLAG AND ADDITION OF TITANIUM OXIDE TRATAMIENTO DEL ACERO CON ESCORIAS SINTÉTICAS DE CALCIO Y ALUMINIO CON ÓXIDO DE TITANIO AÑADIDO

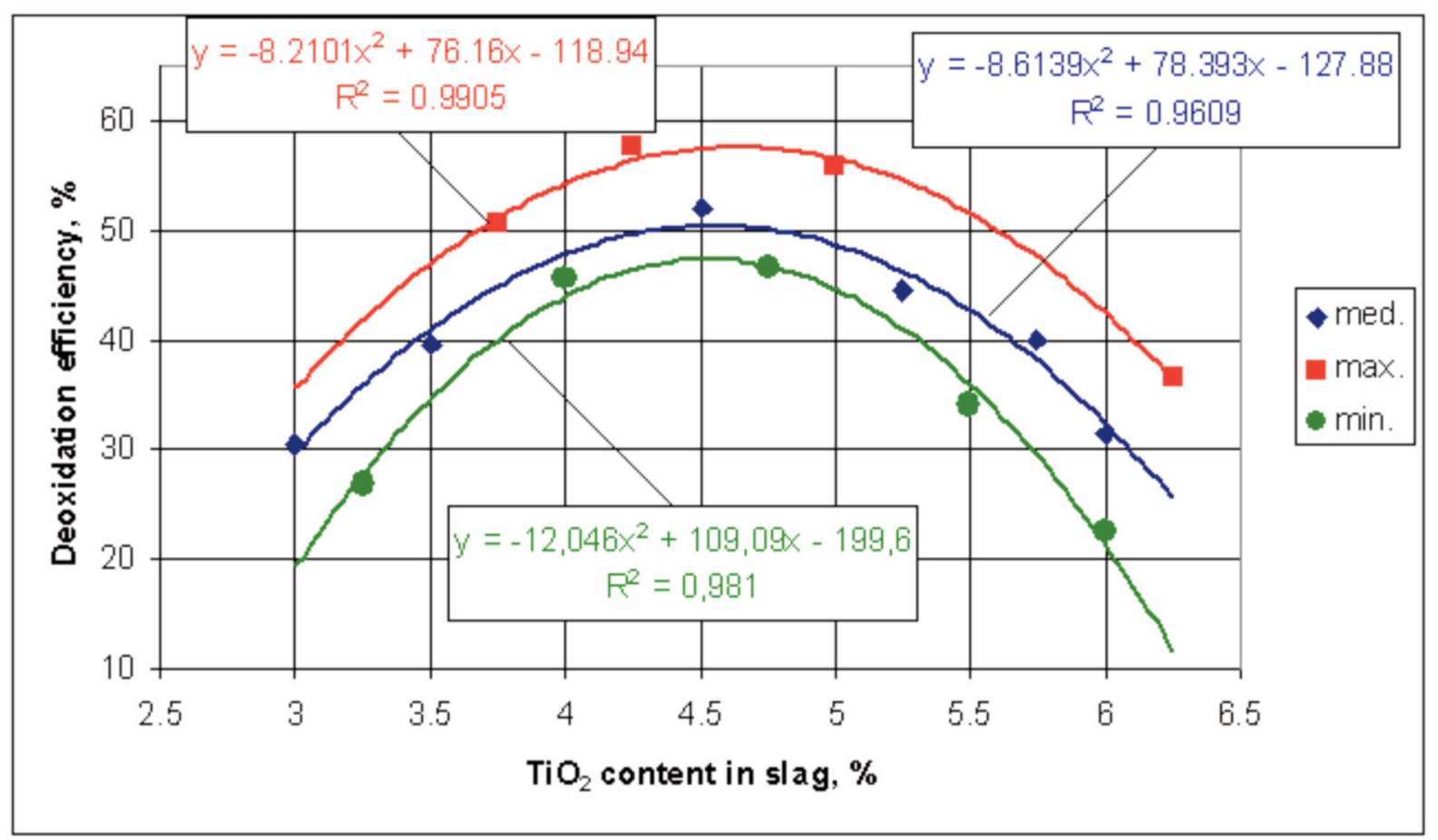

Figure 8. Deoxidation efficiency depending on the content of $\mathrm{TiO}_{2}$ in slag.

Figura 8. Eficiencia de la desoxidación en función del contenido de $\mathrm{TiO}_{2}$ en la escoria.

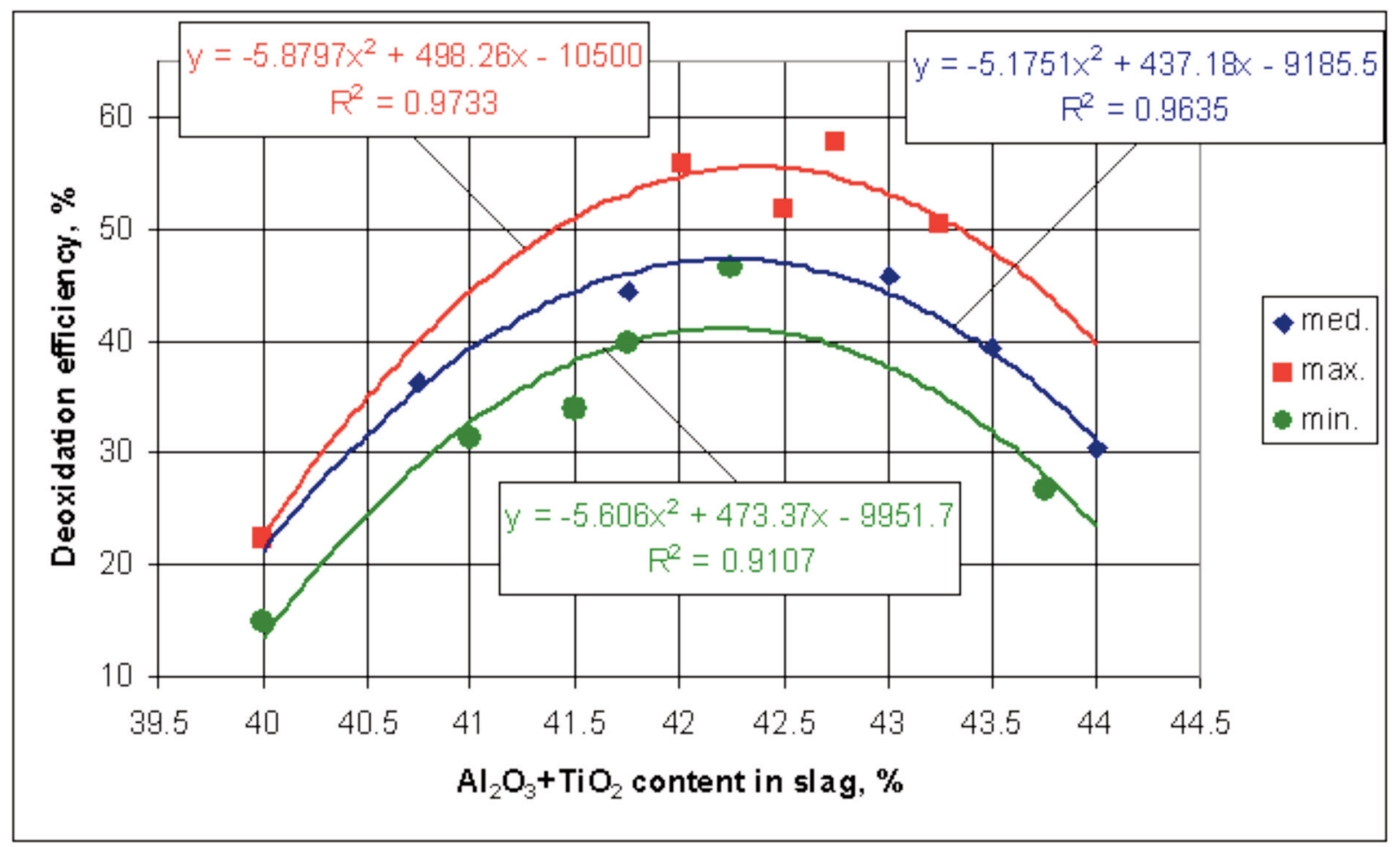

Figure 9. Deoxidation efficiency depending on the content of $\mathrm{Al}_{2} \mathrm{O}_{3}+\mathrm{TiO}_{2}$ in slag.

Figura 9. Eficiencia de la desoxidación en función del contenido de $\mathrm{Al}_{2} \mathrm{O}_{3}+\mathrm{TiO}_{2}$ en la escoria.

Also, for each correlation, the (upper and lower) limits of the variation domain were presented both analytically and graphically for the two dependent parameters, namely the desulphurization and the deoxidizing output. 


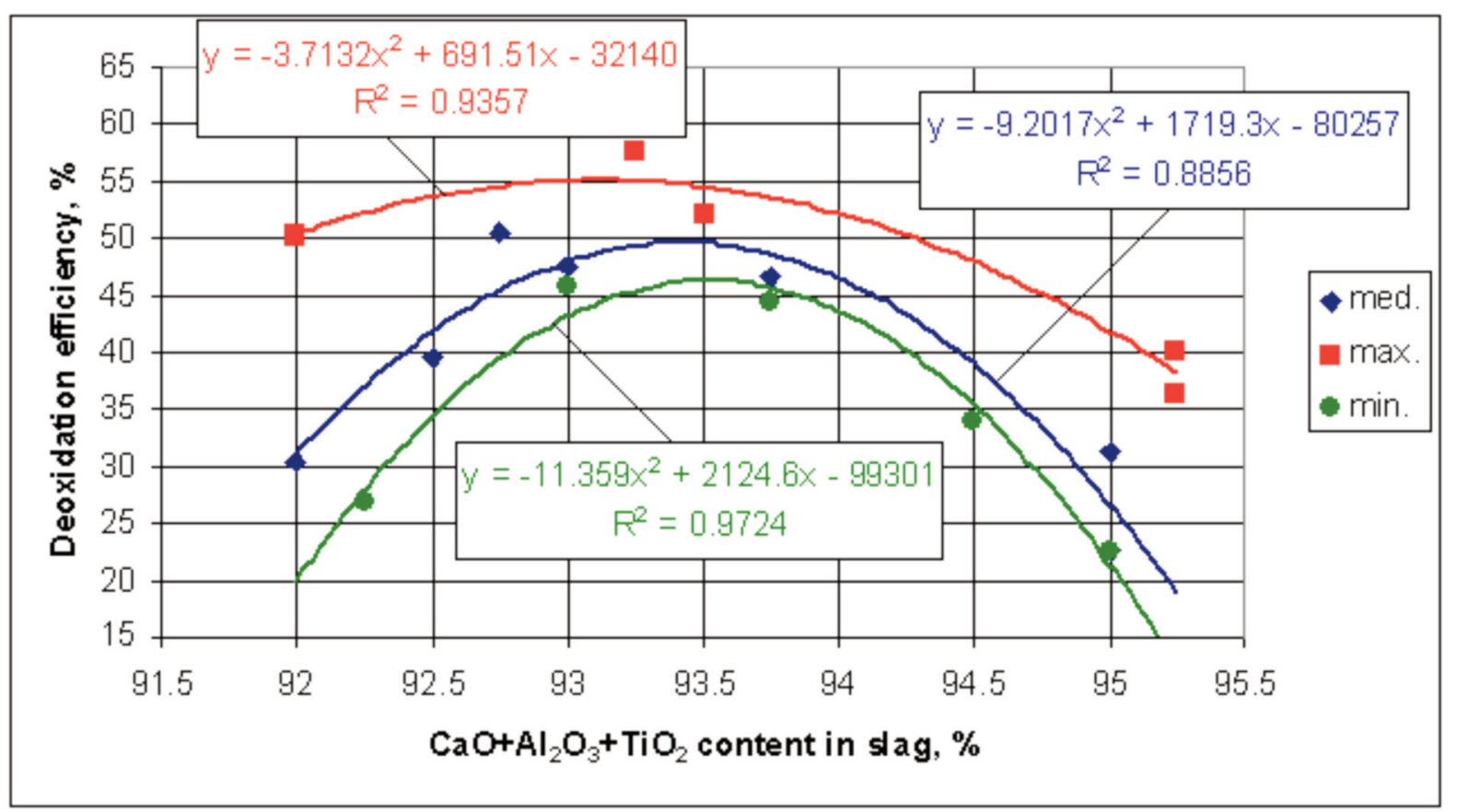

Figure 10. Deoxidation efficiency depending on the content of $\mathrm{CaO}+\mathrm{Al}_{2} \mathrm{O}_{3}+\mathrm{TiO}_{2}$ in slag.

Figura 10. Eficiencia de la desoxidación en función del contenido de $\mathrm{CaO}+\mathrm{Al}_{2} \mathrm{O}_{3}+\mathrm{TiO}_{2}$ en la escoria.

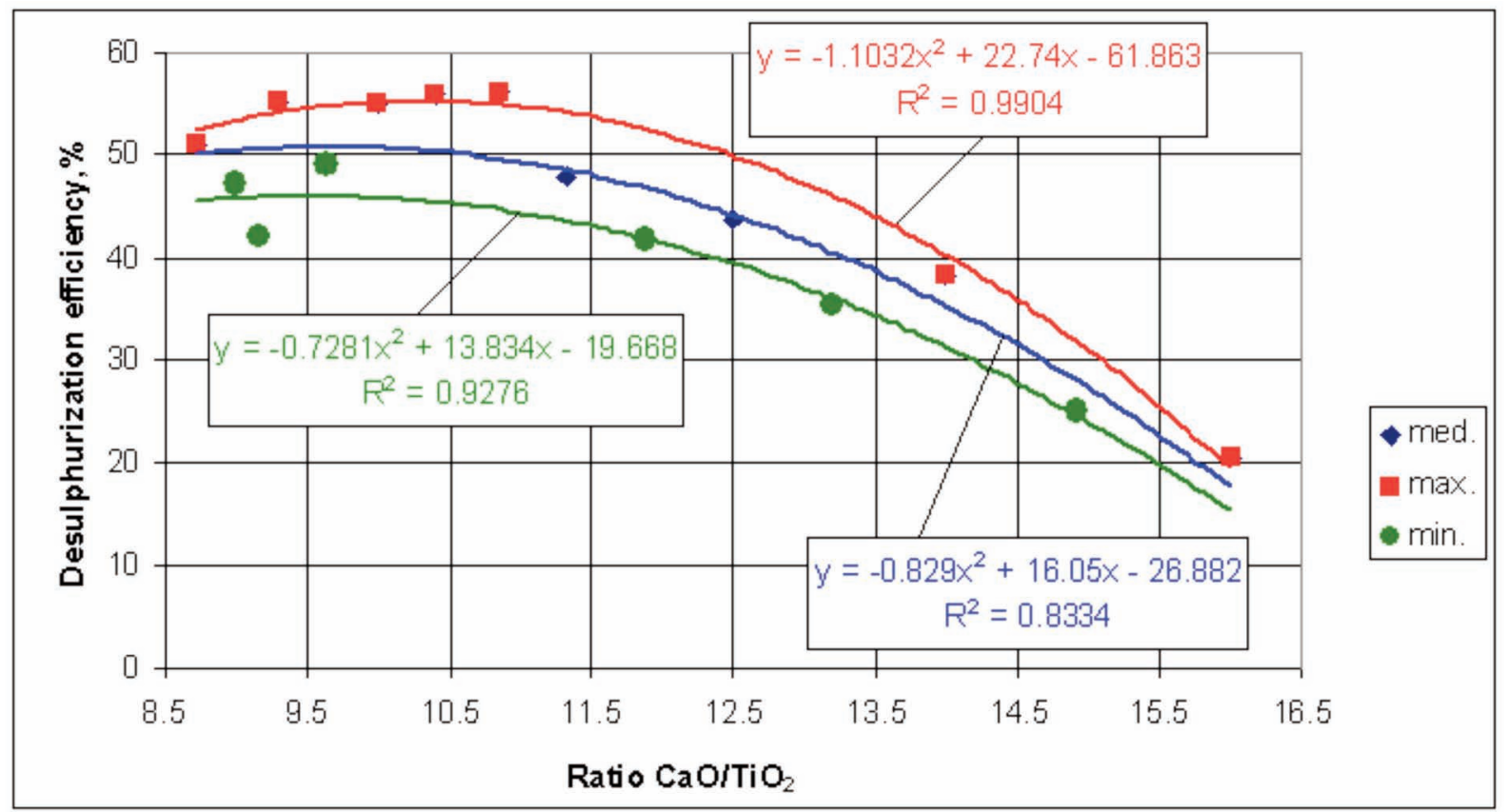

Figure 11. Desulphurization efficiency depending on the ratio of $\mathrm{CaO} / \mathrm{TiO}_{2}$ in slag.

Figura 11. Eficiencia de la desulfuración en función de la relación de $\mathrm{CaO} / \mathrm{TiO}_{2}$ en la escoria.

Considering the values obtained for the correlation coefficients, it ensues that the resulting correlations are representative.
Further on, the results are presented both graphically and analytically. 


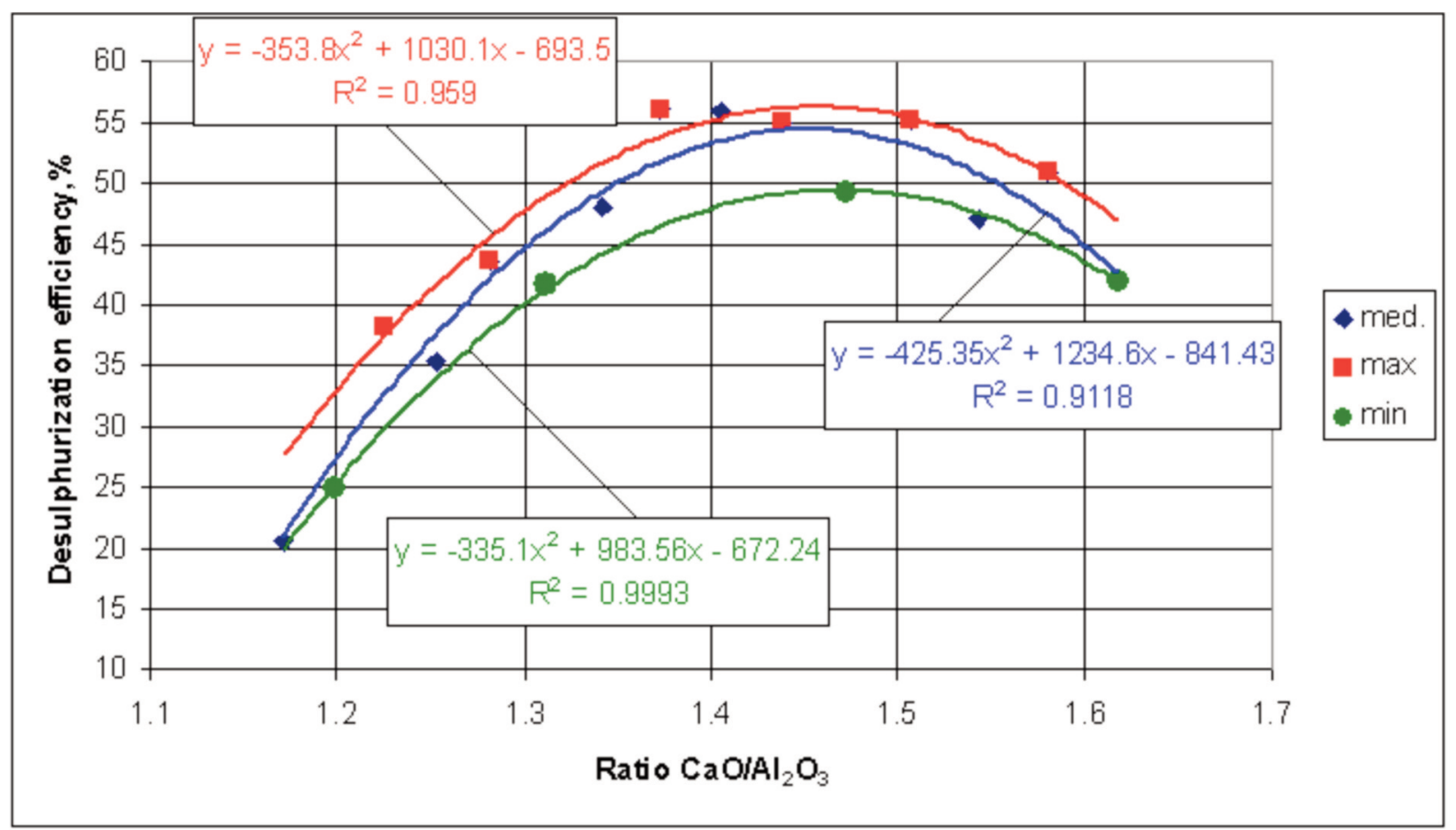

Figure 12. Desulphurization efficiency depending on the ratio of $\mathrm{CaO} / \mathrm{Al}_{2} \mathrm{O}_{3}$ in slag.

Figura 12. Eficiencia de la desulfuración en función de la relación de $\mathrm{CaO} / \mathrm{Al}_{2} \mathrm{O}_{3}$ en la escoria.

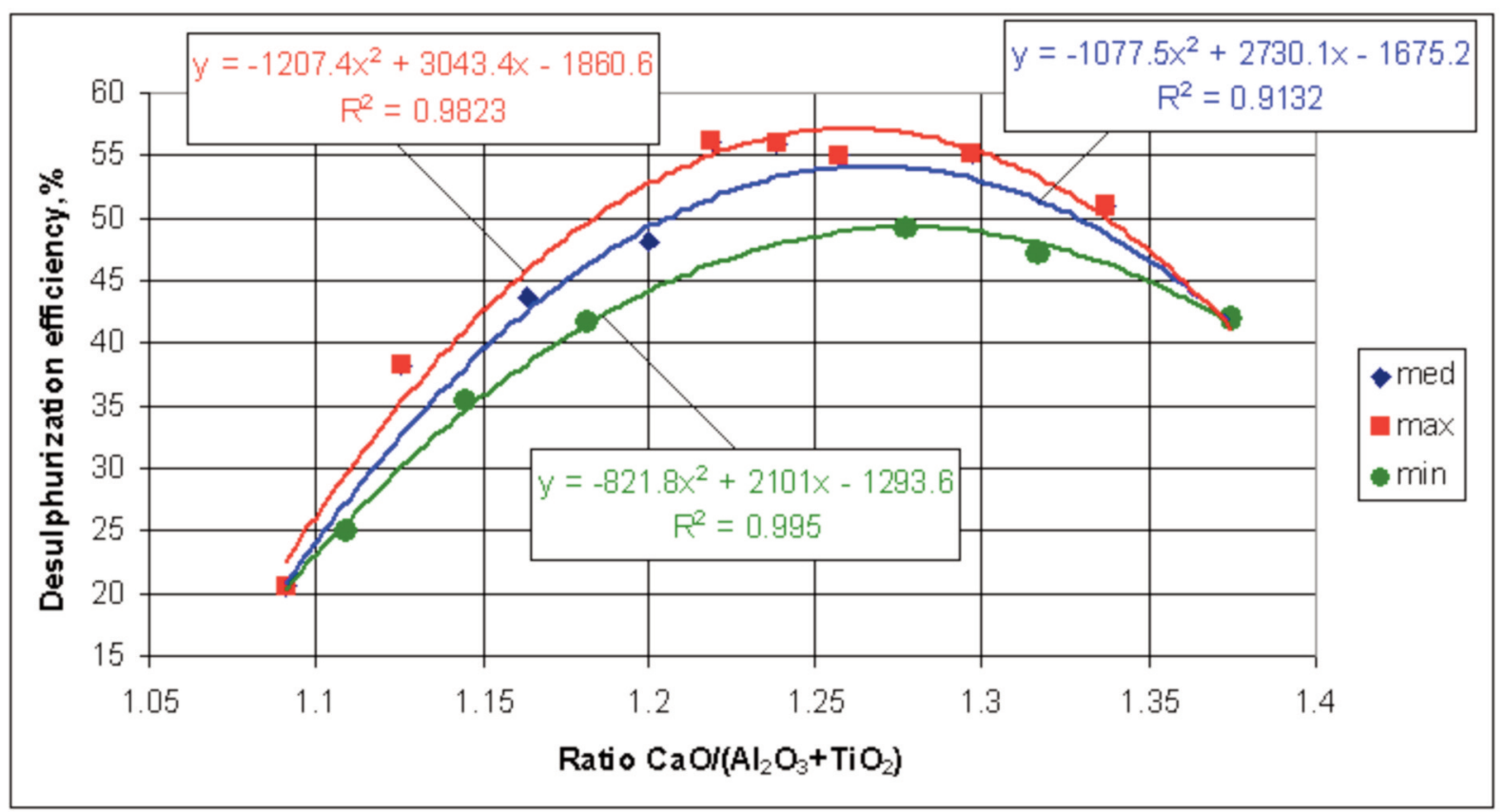

Figure 13. Desulphurization efficiency depending on the ratio of $\mathrm{CaO} /\left(\mathrm{Al}_{2} \mathrm{O}_{3}+\mathrm{TiO}_{2}\right)$ in slag.

Figura 13. Eficiencia de la desulfuración en función de la relación de $\mathrm{CaO} /\left(\mathrm{Al}_{2} \mathrm{O}_{3}+\mathrm{TiO}_{2}\right)$ en la escoria.

\section{DISCUSSION}

A global analysis of the resulting correlations shows that:
- in all cases, the $2^{\text {nd }}$ degree polynomial correlations represent a climax;

- the variation domains are well delimited both at the upper and lower limit; in about $20 \%$ of the 


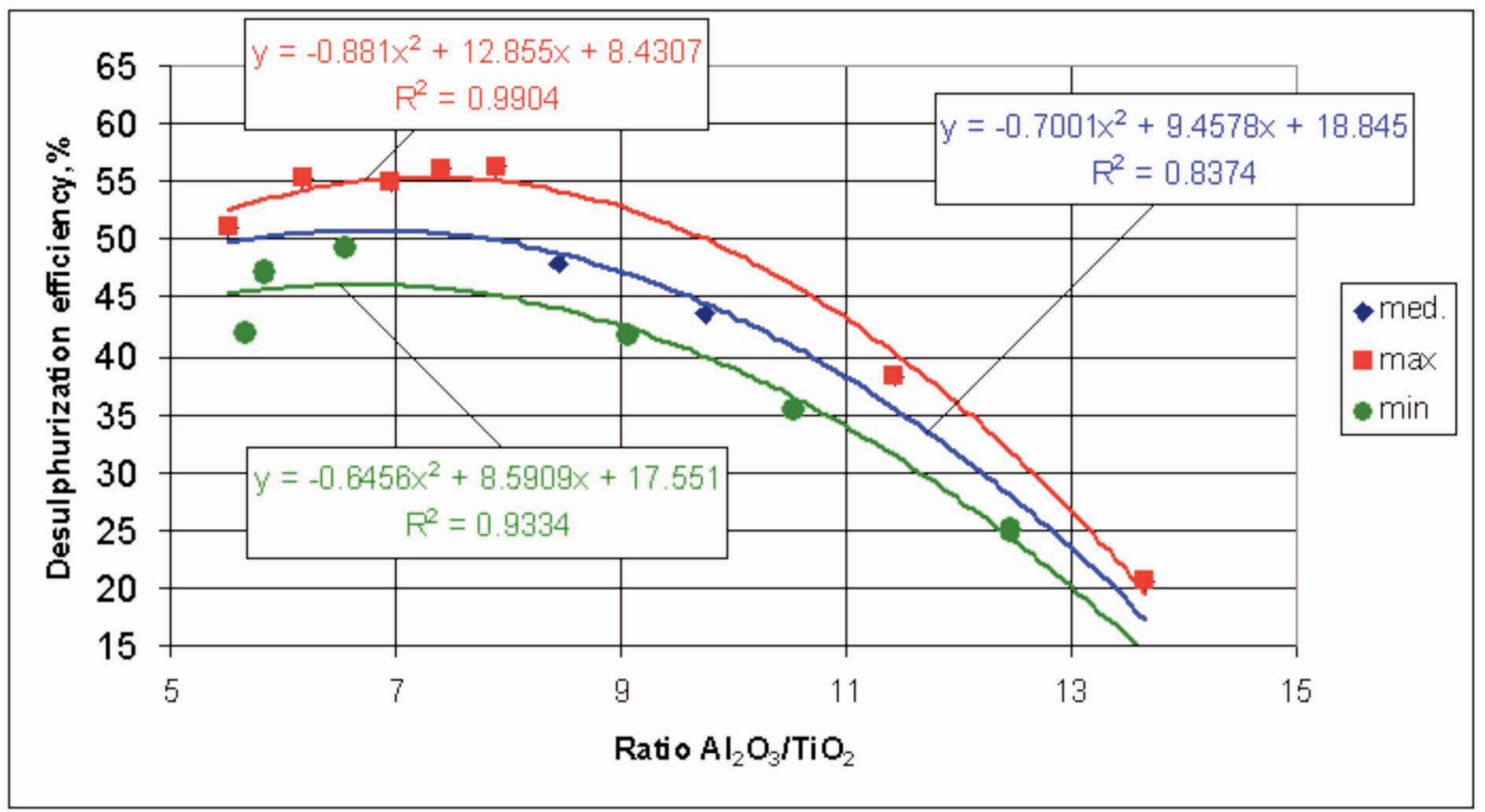

Figure 14. Desulphurization efficiency depending on the ratio of $\mathrm{Al}_{2} \mathrm{O}_{3} / \mathrm{TiO}_{2}$ in slag.

Figura 14. Eficiencia de la desulfuración en función de la relación de $\mathrm{Al}_{2} \mathrm{O}_{3} / \mathrm{TiO}_{2}$ en la escoria.

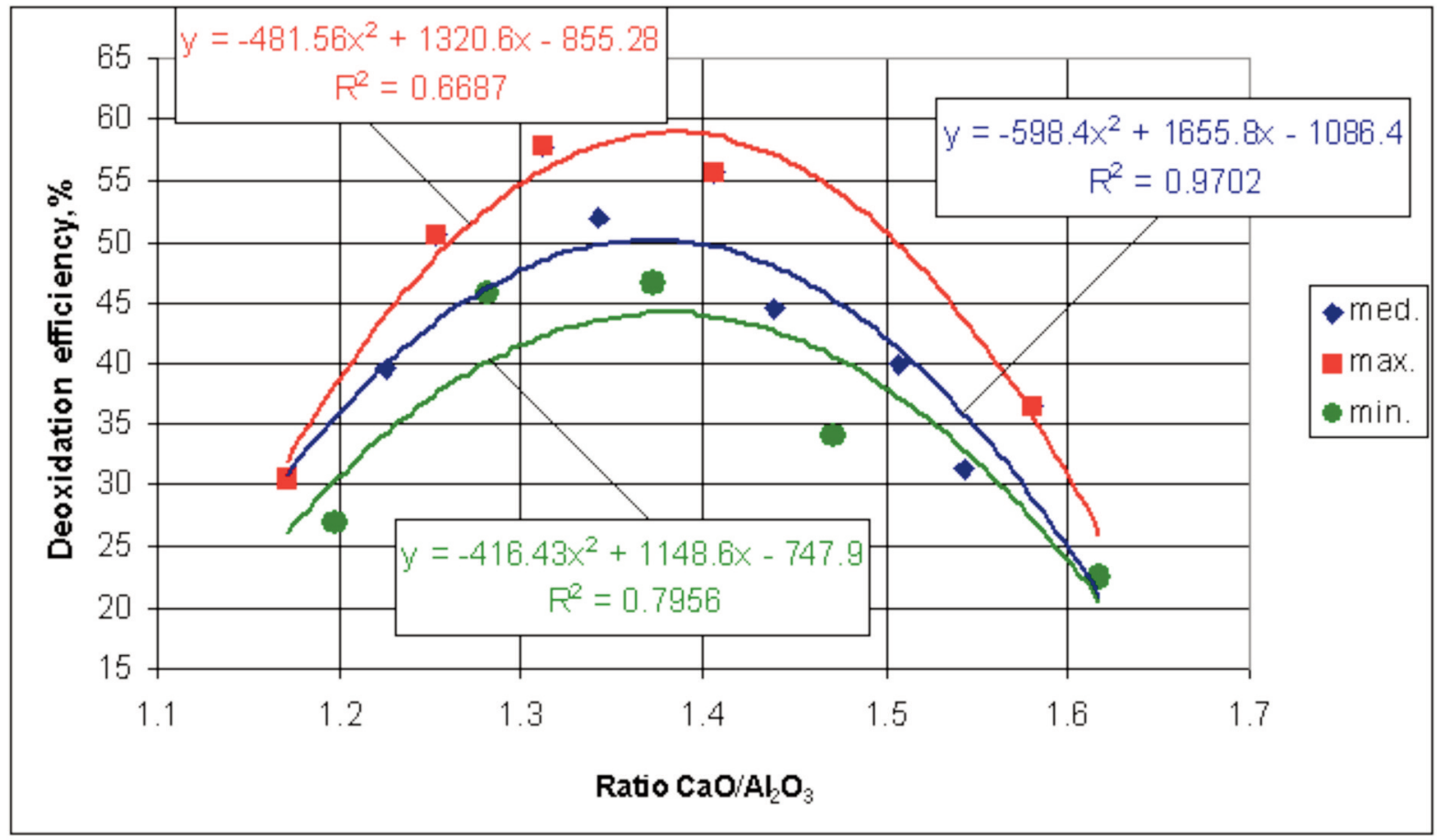

Figure 15. Deoxidation efficiency depending on the ratio of $\mathrm{CaO} / \mathrm{Al}_{2} \mathrm{O}_{3}$ in slag.

Figura 15. Eficiencia de la desoxidación en función de la relación de $\mathrm{CaO} / \mathrm{Al}_{2} \mathrm{O}_{3}$ en la escoria.

instances all the values are ranging within the variation domain and in another $45 \%$ of the cases, up to three values are out of the variation domain;
- both the desulphurization and deoxidizing output vary within large limits, according to the chemical composition of the slag and the ratio 
STEEL TREATMENT WITH CALCIUM-ALUMINATE SYNTHETIC SLAG AND ADDITION OF TITANIUM OXIDE TRATAMIENTO DEL ACERO CON ESCORIAS SINTÉTICAS DE CALCIO Y ALUMINIO CON ÓXIDO DE TITANIO AÑADIDO

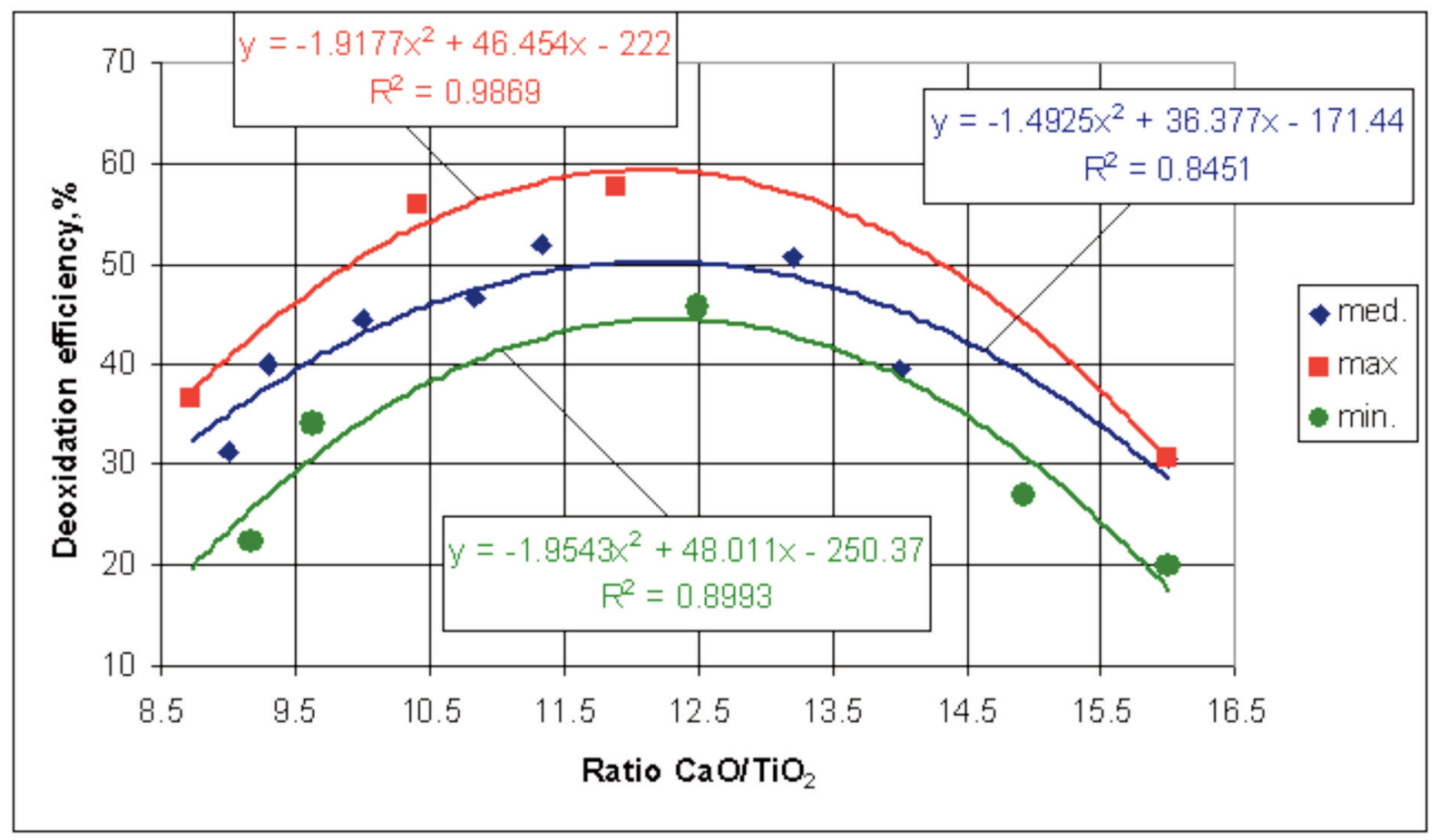

Figure 16. Deoxidation efficiency depending on the ratio of $\mathrm{CaO} / \mathrm{TiO}_{2}$ in slag.

Figura 16. Eficiencia de la desoxidación en función de la relación de $\mathrm{CaO} / \mathrm{TiO}_{2}$ en la escoria.

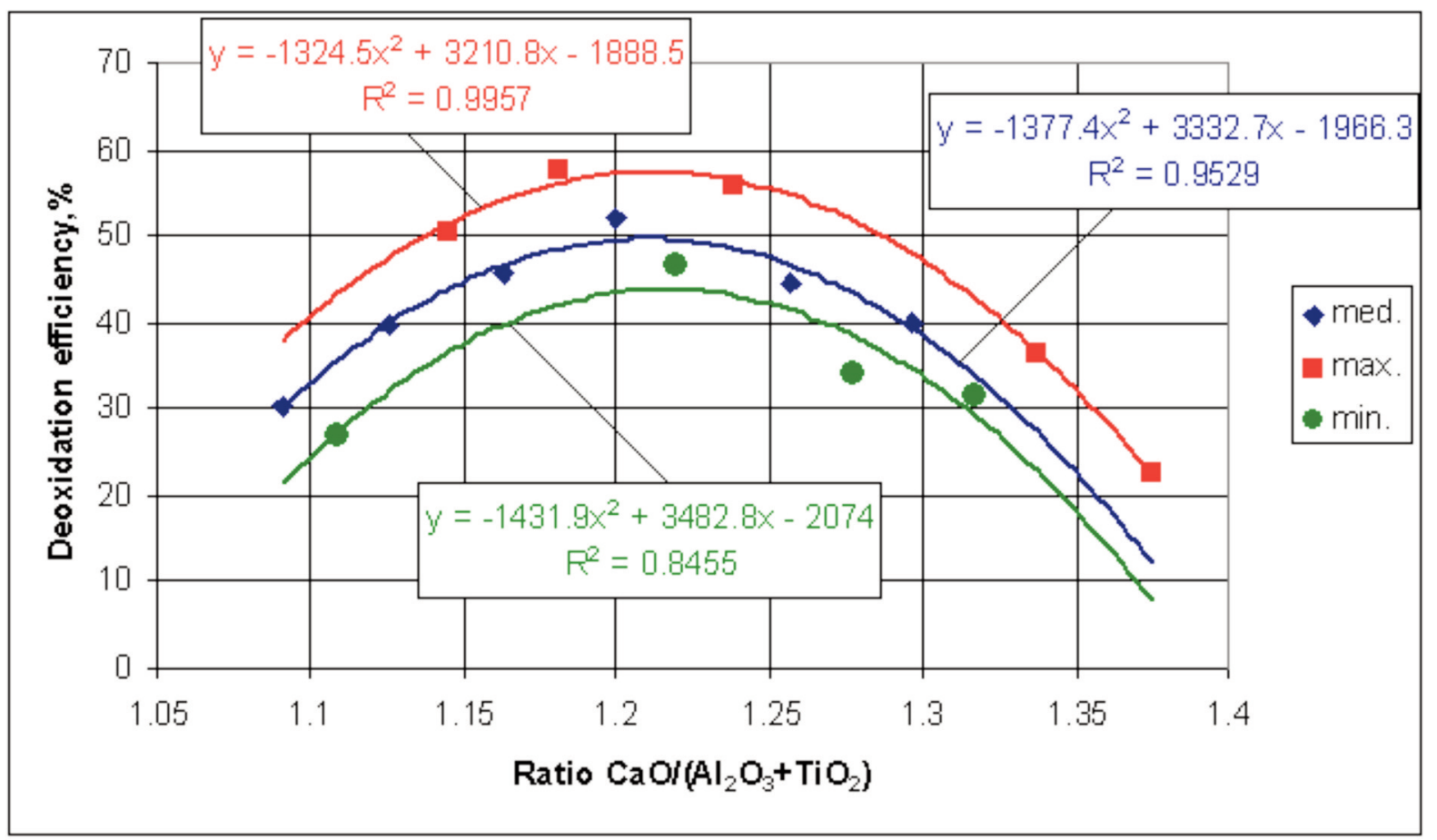

Figure 17. Deoxidation efficiency depending on the ratio of $\mathrm{CaO} /\left(\mathrm{Al}_{2} \mathrm{O}_{3}+\mathrm{TiO}_{2}\right)$ in slag.

Figura 17. Eficiencia de la desoxidación en función de la relación de $\mathrm{CaO} /\left(\mathrm{Al}_{2} \mathrm{O}_{3}+\mathrm{TiO}_{2}\right)$ en la escoria.

between the various oxides, in all cases there existing a maximum point;
- the maximum desulphurization, respectively deoxidizing output has well-defined coordinates; 


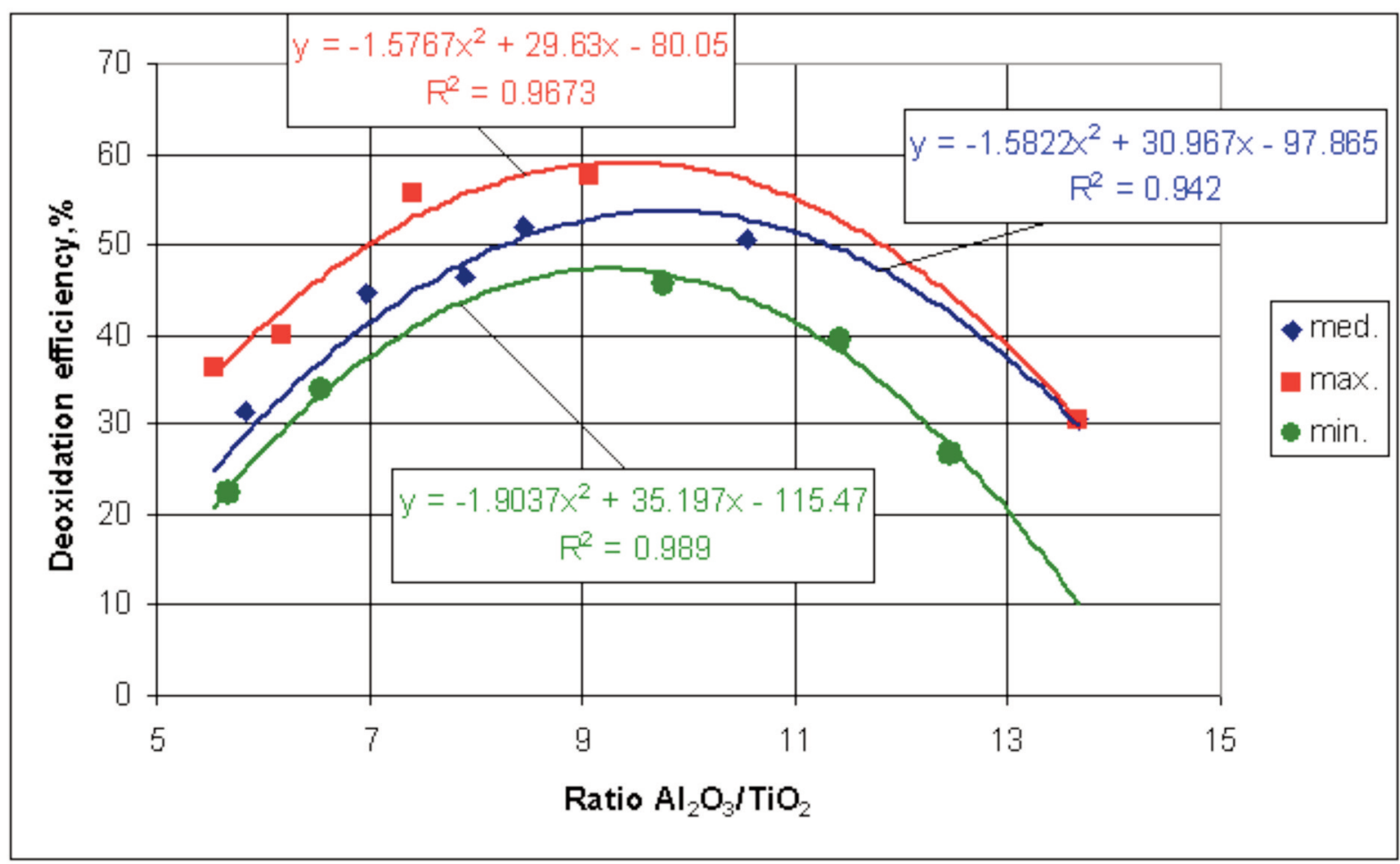

Figure 18. Deoxidation efficiency depending on the ratio of $\mathrm{Al}_{2} \mathrm{O}_{3} / \mathrm{TiO}_{2}$ in slag.

Figura 18. Eficiencia de la desoxidación en función de la relación de $\mathrm{Al}_{2} \mathrm{O}_{3} / \mathrm{TiO}_{2}$ en la escoria.

Table II. Data centralized according to the chemical composition

Tabla II. Datos centralizados según la composición química

\begin{tabular}{|c|c|c|c|c|c|c|c|c|c|}
\hline \multirow{2}{*}{$\mathrm{N}^{\mathrm{O}}$} & \multirow{2}{*}{$\begin{array}{l}\text { Oxide } \\
\text { (sum } \\
\text { oxides) }\end{array}$} & \multirow{2}{*}{ Fig } & \multicolumn{3}{|c|}{ Limits of variation, $\%$} & \multicolumn{2}{|c|}{ Coordinates } & \multirow{2}{*}{$\begin{array}{l}\text { Variation } \\
\text { domain } \\
\text { of choice }\end{array}$} & \multirow{2}{*}{$\begin{array}{l}\text { Resulting } \\
\text { domain }\end{array}$} \\
\hline & & & Oxides & $\eta_{s}$ & $\eta_{0}$ & maximum & minimum & & \\
\hline \multirow{2}{*}{1} & \multirow{2}{*}{$\mathrm{CaO}$} & 1 & \multirow{2}{*}{$48-55$} & $20-57.73$ & - & $52.49 ; 57.73$ & $48 ; 20$ & $50-54$ & $37.60-57.75$ \\
\hline & & 6 & & - & $15.12-57.69$ & $51.28 ; 57.69$ & $55 ; 15$ & $50-54$ & $30.01-57.69$ \\
\hline \multirow{2}{*}{2} & \multirow{2}{*}{$\mathrm{Al}_{2} \mathrm{O}_{3}$} & 2 & \multirow{2}{*}{$34-41$} & $18.25-55.02$ & - & $36.41 ; 55.02$ & $41 ; 18.25$ & $35.5-40$ & $30.82-55.02$ \\
\hline & & $\overline{7}$ & & - & $13.18-57.83$ & $37.72 ; 57.83$ & $34 ; 13.18$ & $35.5-40$ & $31.56-57.83$ \\
\hline \multirow{2}{*}{3} & \multirow{2}{*}{$\mathrm{TiO}_{2}$} & 3 & \multirow{2}{*}{$3-6.25$} & $17.94-54.96$ & - & $5.16 ; 54.96$ & $3 ; 17.94$ & $3.50-5.75$ & $31.21-54.96$ \\
\hline & & 8 & & - & $11.67-57.68$ & $4.64 ; 57.68$ & $6.25 ; 11.67$ & $3.50-5.75$ & $30.02-57.68$ \\
\hline \multirow[t]{2}{*}{4} & $\mathrm{Al}_{2} \mathrm{O}_{3}+$ & 4 & \multirow{2}{*}{$40-44$} & $20.01-55.01$ & - & $41.66 ; 55.01$ & $44 ; 20.01$ & $41.00-43.5$ & $30.01-55.01$ \\
\hline & $\mathrm{TiO}_{2}$ & 9 & & - & $13.5-55.94$ & $42.37 ; 55.94$ & $40 ; 13.5$ & $41.00-43.5$ & $31.44-54.94$ \\
\hline \multirow[t]{2}{*}{5} & \multirow{2}{*}{$\begin{array}{l}\mathrm{CaO}+\mathrm{Al}_{2} \mathrm{O}_{3}+ \\
\mathrm{TiO}_{2}\end{array}$} & \multirow{2}{*}{$\frac{5}{10}$} & \multirow{2}{*}{$92-95.25$} & $19.07-55.33$ & - & $93.99 ; 55.33$ & $92 ; 19.07$ & $92.4-94.75$ & $30.01-55.33$ \\
\hline & & & & - & $20.33-53.03$ & $93.15 ; 53.03$ & $95.25 ; 20.23$ & $92.4-94.75$ & $35.9-53.03$ \\
\hline
\end{tabular}

- starting from the correlations, it is possible to determine the variation limits for the main components, respectively the ratios between the oxides in the slag $\left(\mathrm{CaO}, \mathrm{Al}_{2} \mathrm{O}_{3}, \mathrm{TiO}_{2}\right)$ in view of obtaining high values for the desulphurization and deoxidizing output. 
STEEL TREATMENT WITH CALCIUM-ALUMINATE SYNTHETIC SLAG AND ADDITION OF TITANIUM OXIDE TRATAMIENTO DEL ACERO CON ESCORIAS SINTÉTICAS DE CALCIO Y ALUMINIO CON ÓXIDO DE TITANIO AÑADIDO

Table III. Data centralized according to the oxides ratio

Tabla III. Datos centralizados según la relación de los óxidos

\begin{tabular}{|c|c|c|c|c|c|c|c|c|c|}
\hline \multirow{2}{*}{$\mathrm{N}^{0}$} & \multirow{2}{*}{$\begin{array}{l}\text { Oxide } \\
\text { (ratio) }\end{array}$} & \multirow{2}{*}{ Fig } & \multicolumn{3}{|c|}{ Limits of variation, $\%$} & \multicolumn{2}{|c|}{ Coordinates of the point } & \multirow{2}{*}{$\begin{array}{l}\text { Variation } \\
\text { domain } \\
\text { of choice }\end{array}$} & \multirow{2}{*}{$\begin{array}{c}\text { Variation } \\
\text { domain }\end{array}$} \\
\hline & & & Ratio & $\eta_{s}$ & $\eta_{0}$ & maximum & minimum & & \\
\hline \multirow{2}{*}{1} & \multirow{2}{*}{$\mathrm{CaO} / \mathrm{TiO}_{2}$} & \multirow{2}{*}{$\frac{11}{16}$} & \multirow{2}{*}{$8.72-16$} & $15.28-55.32$ & - & $10.306 ; 55.32$ & $16 ; 15.28$ & $9.50-14$ & $31.30-55.32$ \\
\hline & & & & - & $17.23-55.35$ & $12.13 ; 5.35$ & $16 ; 17.23$ & $9.5-14$ & $32.65-55.35$ \\
\hline \multirow{2}{*}{2} & \multirow{2}{*}{$\mathrm{CaO} / \mathrm{Al}_{2} \mathrm{O}_{3}$} & \multirow{2}{*}{$\frac{12}{15} 1$} & \multirow{2}{*}{$.171-1.618$} & $20.17-56.50$ & - & $1.45 ; 56.50$ & $1.171 ; 20.17$ & $1.23-1.55$ & $31.35-56.50$ \\
\hline & & & & - & $19.86-54.14$ & $1.37 ; 54.15$ & $1.618 ; 19.86$ & $1.23-1.55$ & $31.54-57.22$ \\
\hline \multirow[t]{2}{*}{3} & \multirow{2}{*}{$\begin{array}{l}\mathrm{CaO} / \mathrm{Al}_{2} \mathrm{O}_{3}+ \\
\mathrm{TiO}_{2}\end{array}$} & \multirow{2}{*}{$\frac{13}{17}$} & \multirow{2}{*}{$1.091-1.375$} & $20.42-57.22$ & - & $1.26 ; 57.22$ & $1.091 ; 20.42$ & $1.13-1.31$ & $31.17-57.22$ \\
\hline & & & & 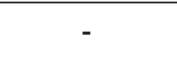 & $3.23-53.74$ & $1.21 ; 53.74$ & $1.375 ; 3.23$ & $1.13-1.31$ & $30.67-53.74$ \\
\hline \multirow{2}{*}{4} & \multirow{2}{*}{$\mathrm{Al}_{2} \mathrm{O}_{3} / \mathrm{TiO}_{2}$} & \multirow{2}{*}{$\frac{14}{18} 5$} & \multirow{2}{*}{$5.52-13.667$} & $14.37-55.32$ & - & $7.30 ; 55.32$ & $13.667 ; 14.37$ & $6-11.2$ & $32.80-55.32$ \\
\hline & & & & - & $10.37-55.80$ & $9.33 ; 55.80$ & $13.667 ; 10.37$ & $6-11.2$ & $30.30-55.80$ \\
\hline
\end{tabular}

The analysis of the correlation diagrams given in figures $1-10$, respectively $11-18$, and of the centralized data shown in tables II and III, leads to the following conclusions:

- in order to obtain a desulphurization and deoxidizing degree of at least $30 \%$, the oxides have to range within the following limits: $\mathrm{CaO}=50-54 \%$; $\mathrm{Al}_{2} \mathrm{O}_{3}=35.5-41 \%$, and $\mathrm{TiO}_{2}=3-6.25 \%$, so, within variation limits that are narrower than those envisaged by the experiments;

- with respect to the three basic oxides, it is desirable that their content vary within the suggested limits, but the following conditions are also to be met: $\mathrm{Al}_{2} \mathrm{O}_{3}+\mathrm{TiO}_{2}=41.00-43.50 \%$, and $\mathrm{CaO}+\mathrm{Al}_{2} \mathrm{O}_{3}+$ $\mathrm{TiO}_{2}=92.4-94.75 \%$,

- as to the ratio of the main oxides $\mathrm{CaO} / \mathrm{Al}_{2} \mathrm{O}_{3}$, $\mathrm{CaO} / \mathrm{TiO}_{2}$ and $\mathrm{Al}_{2} \mathrm{O}_{3} / \mathrm{TiO}_{2}$, thay have to vary within the limits: $\mathrm{CaO} / \mathrm{Al}_{2} \mathrm{O}_{3}=1.23-1.55 ; \mathrm{CaO} / \mathrm{TiO}_{2}=9.50-14.00$ and $\mathrm{Al}_{2} \mathrm{O}_{3} / \mathrm{TiO}_{2}=6.00-11.2$, so that the desulphurization and deoxidizing degree should be of at least $30 \%$;

- concerning the ratios given above, it is desirable that they vary within the suggested limits, but the following condition has also to be met: $\mathrm{CaO} /\left(\mathrm{Al}_{2} \mathrm{O}_{3}+\mathrm{TiO}_{2}\right)=1.13-1.31$.

The conditions given above can be observed and met technologically and therefore it is possible to ensure for $\eta_{S}$, respectively $\eta_{O}$, values within the interval $30 \%-58 \%$.

\section{CONCLUSIONS}

- Mechanical mixtures based on lime, alumina and titanium oxide, respectively the slag resulting from their melting, grant favorable condition for steel refining inside the ladle through the method called "synthetic slag treatment".

- A mechanical mixture whose oxide values (the sum of the oxides) range within limits close to the climax leads to high values for $\eta_{S}$, respectively $\eta_{\mathrm{O}}$

- In the case of variation of the oxide ratios in the vicinity of the climax, it is possible to obtain for $\eta_{S}$, respectively $\eta_{O}$ values next to the upper limit.

- The results obtained lead to the idea of continuing the experiments by using as one component of the mechanical mixture, the slag resulted from the production of ferrotitanium.

- Laboratory experiments shall continue in view of determining the optimal quantity of slag $(\mathrm{kg} / \mathrm{t}$ of molten steel), as well as the duration of the treatment in order to obtain the best results in steel refining.

\section{REFERENCES}

[1] I. Tripsa and C. Pumnea, Steel deoxidation, Tehnica Publishing House (Eds.), Bucarest, 1981, p. 332.

[2] S. Vacu, Elaboration of alloy steel, Vol. I, Tehnica Publishing House (Eds.), Bucarest, 1980, p. 250.

[3] I. Butnariu and V. Geanta, Special technology development and refining of steels, UPB 
A. Putan, V. Putan, T. Heput and A. Socalici

Publishing House (Eds.), Bucarest, 1993, pp. 120-124.

[4] T. Heput, E. Ardelean and I. Kiss, Rev. Metal. Madrid 41(2005) 220-226.
[5] T. Heput, E. Ardelean, A. Socalici, ST. Maksay, and A. Gavanescu, Rev. Metal. Madrid 41 (2007) 181-187. 